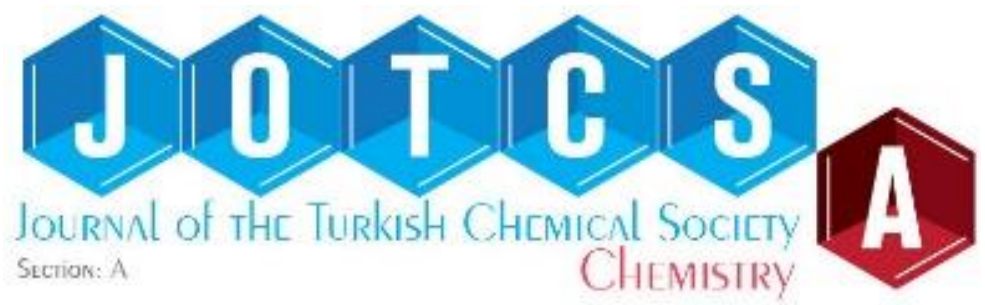

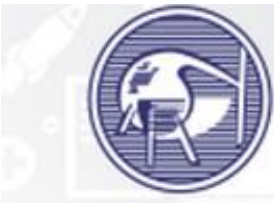

TURKISH

CHEMICAL SOCIETY

\title{
A Schiff Base Sensor Selective to Anions, Biological Activity, and Spectral Studies
}

\author{
Nuray Yıldırım (D) Mustafa Yıldız ${ }^{2 *}$ (D) \\ ${ }^{1}$ Health Services Vocational School, Çanakkale Onsekiz Mart University, TR-17100 Çanakkale, Turkey \\ ${ }^{2}$ Department of Chemistry, Faculty of Arts and Sciences, Çanakkale Onsekiz Mart University, 17100 \\ Çanakkale, Turkey
}

\begin{abstract}
In this study, synthesis, characterization, anion sensor properties, and DNA binding of a benzothiazole-based Schiff base 4-bromo-2-((6-methoxybenzo[d]thiazol-2-ylimino)methyl)phenol have been investigated. The structure of the Schiff base was revealed with elemental analysis and spectroscopic methods. The colorimetric and fluorescent anion sensor properties of the Schiff base in DMSO were investigated by adding an equivalent amount of anions. In this context, the solution containing Schiff base had a color change after the addition of $\mathrm{F}^{-}, \mathrm{CN}^{-}, \mathrm{AcO}^{-}, \mathrm{H}_{2} \mathrm{PO}_{4}^{-}$and $\mathrm{OH}^{-}$anions, while the color change was not observed with the addition of $\mathrm{Br}^{-}, \mathrm{I}^{-}, \mathrm{SCN}^{-}, \mathrm{ClO}_{4}^{-}$and $\mathrm{HSO}_{4}^{-}$anions. The anion-binding power of the compound was found to be $\mathrm{F}^{-}>\mathrm{OH}^{-}>\mathrm{AcO}^{-}>\mathrm{CN}^{-}>\mathrm{H}_{2} \mathrm{PO}_{4}^{-}$using UV-Vis spectrophotometry, respectively. The antimicrobial activity of the compound was investigated against some microorganisms. The compound showed activity against bacteria and yeast. Schiff base showed a similar effect against both bacteria and yeast. Interactions between the compound and CT-DNA were studied with UV-Vis spectra. The UV-Vis experiment results confirm that the Schiff base binds to CT-DNA in an intercalative mode. The compound did not show any cleavage effect on SC DNA as hydrolytic and oxidative.
\end{abstract}

Keywords: Schiff base, Spectroscopy, Anion Sensors, DNA-Binding.

Submitted: June 06, 2018. Accepted: October 31, 2018.

Cite this: Yıldırım N, Yıldız M. A Schiff Base Sensor Selective to Anions, Biological Activity, and Spectral Studies. JOTCSA. 2018;5(3):1271-8.

DOI: http://dx.doi.org/10.18596/jotcsa.431554.

*Corresponding author. E-mail; myildiz@comu.edu.tr, Fax: (0)286-218-0533, Tel: (0)286-218$0018 / 1861$

\section{INTRODUCTION}

Some characteristic properties of Schiff bases, such as antimicrobial, antioxidant, anticancer, anti-helmintic, anti-inflammatory, anticonvulsant, antitubercular and analgesic activities (1-5) as well as chemosensory and DNA binding properties (6-19) have been reported. The technique used in chemosensors is concerned with the quenching of the colorimetric chemosensor of fluorescence by interaction with various anions. Chemosensors are very useful because they provide fast and visible color changes in the presence of ions. In the last decade, many chemosensors have been developed and studied to recognize and select ions with precise selectivity and sensitivity (420).
2-Hydroxy imines exhibit interesting properties both in solution and solid state. Tautomerism occurs in ortho-hydroxy imines. It was studied in ortho-hydroxy imines using various methods $(21,22)$. If the $\mathrm{H}$ proton in the $\mathrm{O}-\mathrm{H}$ is taken by the imine nitrogen, the keto-amine form occurs. This form is always observed if the imine is formed by 2-hydroxy-1-naphthaldehyde and aromatic amine. It is not observed in solution and solid state in Schiff bases composed of 2-hydroxy benzaldehyde and aromatic amines. But it has been observed in compounds derived from substituted salicylaldehydes and aromatic amines. Many properties of Schiff bases, especially sensor properties, are associated with tautomerism. Depending on the tautomerism of 
the ortho-hydroxy imines, hydrogen bonds such as $\mathrm{O}-\mathrm{H}$... N and $\mathrm{N}-\mathrm{H}$...O are formed $(21,23)$.

Colorimetric sensors are used for ion detection because the signaling phenomenon is easily detected by the naked eye $(22,24)$. A visible color change occurs after the formation of the hydrogen bond between the anion and the sensor. 2-Hydroxy Schiff bases can produce hydrogen bonds that can be used in chromogenic and fluorogenic sensors $(11,25)$. Benzothiazolebased Schiff bases are nitrogen and sulfurheterocyclic bicyclic ring systems (26). Benzothiazoles have many applications. Anticancer, antimicrobial and antidiabetic, anticonvulsant, anti-inflammatory, antiviral, and antitubercular activities of benzothiazoles are known $(27,28)$. Furthermore, biological activities of bicyclic Schiff bases have been investigated and reported as DNA repair agents (29).

In the present work, a receptor was prepared by the reaction of 2-amino-6-methoxybenzothiazole with 5-bromosalicylaldehyde with the ability to detect some anions by colorimetry and spectrophotometry (UV-Vis) in dimethyl sulfoxide (DMSO). In addition, the antimicrobial activity of the synthesized compound and its interaction with DNA was investigated.

\section{MATERIALS AND METHODS}

\section{Reagents and techniques}

The ${ }^{1} \mathrm{H}$ - and ${ }^{13} \mathrm{C}$-NMR spectra were recorded on a JOEL NMR- 400 spectrometer operating at 400 and $101,6 \mathrm{MHz}$, respectively. Infrared absorption spectra were obtained from a Perkin Elmer BX II spectrometer in $\mathrm{KBr}$ discs and were reported in $\mathrm{cm}^{-1}$ units. The UV-Vis spectra were measured using $P G$ Instruments $T+80$ UV/Vis spectrophotometer. Elemental analyses were performed on a Vario EL III CHNS elemental analyzer. Melting points were measured with an Electro Thermal IA 9100 apparatus using a

capillary tube. 2-Amino-6-methoxybenzothiazole, 5-bromosalicylaldehyde, EtOH, DMSO, Ethidium bromide (EB), calf thymus DNA (CT-DNA), $(\mathrm{Bu})_{4} \mathrm{NF}, \quad(\mathrm{Bu})_{4} \mathrm{NBr}, \quad(\mathrm{Bu})_{4} \mathrm{NI}, \quad(\mathrm{Bu})_{4} \mathrm{NCN}$, (Bu) ${ }_{4} \mathrm{NSCN} \quad(\mathrm{Bu})_{4} \mathrm{NClO}_{4}, \quad(\mathrm{Bu})_{4} \mathrm{NHSO}_{4}$, (Bu) ${ }_{4} \mathrm{NCH}_{3} \mathrm{COO}, \quad(\mathrm{Bu})_{4} \mathrm{NH}_{2} \mathrm{PO}_{4}, \quad(\mathrm{Bu})_{4} \mathrm{NN}_{3}$, $(\mathrm{Bu})_{4} \mathrm{NOH}$ and DMSO were purchased from Aldrich. The Tris- $\mathrm{HCl}$ buffer solution was prepared with triple-distilled water. CT-DNA stock solution was prepared by diluting DNA to Tris- $\mathrm{HCl} / \mathrm{NaCl}$ buffer ( $5 \mathrm{mM}$ Tris- $\mathrm{HCl}, 50 \mathrm{mM} \mathrm{NaCl}, \mathrm{pH} 7.2$ ), and kept at $4^{\circ} \mathrm{C}$ for no longer than two days.

\section{Synthesis of 4-bromo-2-((6- methoxybenzo[d]thiazol-2- ylimino)methyl)phenol}

2-Amino-6-methoxybenzothiazole $(1.00 \mathrm{~g} ; 5.55$ $\mathrm{mmol})$, ethanol (100 $\mathrm{mL})$ and 5-bromo-2hydroxybenzaldehyde $(1.115 \mathrm{~g} ; 5.55 \mathrm{mmol})$ were added to a $250 \mathrm{~mL}$ round-bottomed flask. The mixture was stirred and refluxed for $2 \mathrm{~h}$. The compound was obtained from the evaporation of ethanol and was crystallized from $\mathrm{CHCl}_{3}: \mathrm{n}$ hexane (3:1) as a yellow crystal, m.p. 213-215 ${ }^{\circ} \mathrm{C}, \quad 1.79 \mathrm{~g}$ (89\%) yield (Scheme 1). Experimental: $\mathrm{C}, 49.05 ; \mathrm{H}, 3.05 ; \mathrm{N}, 7.71$. Calculated: $\mathrm{C}_{15} \mathrm{H}_{11} \mathrm{BrN}_{2} \mathrm{O}_{2} \mathrm{~S} ; \mathrm{C}, 49.58 ; \mathrm{H}, 3.04 ; \mathrm{N}$, 7.71. FT-IR ( $\left.\mathrm{KBr}, \mathrm{cm}^{-1}\right)$ vO-H; $3291 \mathrm{~m}-\mathrm{br}, \mathrm{vAr}-\mathrm{H}$; 3077 w, vC-H; 2974-2925 w, vC=N; 1598 s, $v \mathrm{C}=\mathrm{C} ; 1558 \mathrm{~s}, v \mathrm{C}-\mathrm{N} ; 1497 \mathrm{~s}, v \mathrm{C}-\mathrm{O} ; 1346 \mathrm{~s}, v \mathrm{C}-$ O-C; $1262-1220-1169-1050$ s. ${ }^{1} \mathrm{H}-\mathrm{NMR}$ (DMSO); $\delta \mathrm{ppm}, 9.30(\mathrm{~s}, 1 \mathrm{H}, \mathrm{Ar}-\mathrm{OH}) ; 8.06(\mathrm{~s}, 1 \mathrm{H}, \mathrm{Ar}-$ $\mathrm{C} \underline{\mathrm{H}}=\mathrm{N}-) ; 7.85-6.98(\mathrm{~m}, 6 \mathrm{H}, \quad \mathrm{Ar}-\underline{\mathrm{H}}) .{ }^{13} \mathrm{C}-\mathrm{NMR}$ (DMSO); $\delta \mathrm{ppm}, 168.10$ (s, 1C, $\underline{\mathrm{C} 8}$ ); 163.08 (s, 1C, C7) ; 159.85 (s, 1C, C2); 157.91 (s, 1C, C13); 145.86 (s, 1C, C10); 137.78 (s, 1C, C9); 135.93 (s, 1C, C6) ; 132.28 (s, 1C, C11); 123.90 (s, 1C, C4); 122.25 (s, 1C, C1); 119.82 (s, 1C, C3); 116.48 (s, 1C, C12); 111.23 (s, 1C, C5); 105.56 (s, 1C, $\mathrm{C14}$ ); 56.19 (s, 1C, C15). The carbons were numbered according to the order of Scheme 1 .<smiles>COc1ccc2nc(N)sc2c1</smiles>

Scheme 1. Synthesis of the Schiff base.

\section{Screening for antimicrobial activities}

Staphylococcus aureus ATCC 25923, Enterococcus faecalis ATCC 29212, Escherichia coli ATCC 25922, Pseudomonas aeruginosa ATCC 254992, Candida albicans ATCC 60193, and Candida tropicalis ATCC 13803 were used as microorganisms. Ampicillin and fluconazole were used as controls in this study as they are wellknown broad-spectrum antibiotics that have different mechanisms of activity, such as interruption of cell wall synthesis (ampicillin) (30). The compounds were dissolved in DMSO (dimethyl sulfoxide) to a final concentration of $500 \mu \mathrm{g} / \mathrm{mL}$. The concentration of the compounds on different plates was $500 \mu \mathrm{g} / \mathrm{mL}, 250 \mu \mathrm{g} / \mathrm{mL}$, $125 \mu \mathrm{g} / \mathrm{mL}, 62.5 \mu \mathrm{g} / \mathrm{mL}, 31.25 \mu \mathrm{g} / \mathrm{mL}, 15.6$ $\mu \mathrm{g} / \mathrm{mL}, 8 \mu \mathrm{g} / \mathrm{mL}, 4 \mu \mathrm{g} / \mathrm{mL}, 2 \mu \mathrm{g} / \mathrm{mL}$, and 1 $\mu \mathrm{g} / \mathrm{mL}$. 


\section{DNA-Binding experiments}

The UV-Visible spectral titrations were carried out in Tris- $\mathrm{HCl} / \mathrm{NaCl}$ buffer at room temperature to investigate the binding affinity between CT-DNA and the Schiff base. The UV-Vis absorbance at 260 and $280 \mathrm{~nm}$ of CT-DNA solution in Tris buffer gives a ratio of $1.8-1.9$, indicating that the DNA was sufficiently free of the protein (31). Tris$\mathrm{HCl} / \mathrm{NaCl}$ buffer $(1.8 \mathrm{~mL})$ and the solutions of Schiff base $\left(1.8 \mathrm{~mL}, 1 \times 10^{-5} \mathrm{M}\right)$ were respectively placed into two cuvettes. Then one aliquot (5.4 $\mu \mathrm{L}, 0.01 \mathrm{M}$ ) of buffered CT-DNA solution was added to each cuvette in order to eliminate the absorbance of DNA itself. Before the absorption spectra were recorded, the Schiff base-DNA solutions were incubated at room temperature for $5 \mathrm{~min}$.

\section{DNA Cleavage experiments}

The DNA cleavage activity of the Schiff base was studied by agarose gel electrophoresis method. pBR322 DNA $\left(0.1 \mu \mathrm{g} \mathrm{LL}^{-1}\right)$ in Tris-HCl buffer $(10$ $\mu \mathrm{M}, \mathrm{pH}: 7,2)$ treated with the compound at $37^{\circ} \mathrm{C}$ for $3 \mathrm{~h}$. To determine the mechanism of cleavage activity $\mathrm{H}_{2} \mathrm{O}_{2}$ was added to one of the group of mixture as an oxidizing agent. After incubation loading buffer was added and samples were subjected to electrophoresis for 1 hour at $60 \mathrm{~V}$ on $1 \%$ agarose gel in TBE (Tris-Boric acid-EDTA, $\mathrm{pH}: 8.0)$ buffer. Then, the bands were visualized by UV light and photographed.

\section{Anion Sensors Measurements}

The Schiff base $(0.05 \mu \mathrm{mol})$ was dissolved in DMSO (50 mL). Tetrabutylammonium salts $\left(\mathrm{F}^{-}, \mathrm{Br}^{-}\right.$ , $\mathrm{I}^{-}, \mathrm{CN}^{-}, \mathrm{SCN}^{-}, \mathrm{ClO}_{4}^{-}, \mathrm{HSO}_{4}^{-}, \mathrm{CH}_{3} \mathrm{COO}^{-}, \mathrm{H}_{2} \mathrm{PO}_{4}^{-}$, $\left.\mathrm{OH}^{-}\right)(0.05 \mu \mathrm{mol})$ were dissolved in DMSO (50 $\mathrm{mL}$ ). Each solution of tetrabutylammonium salts was added to the Schiff base solution (1:1) in the tube. After mixing them, UV absorption spectra and the photos were taken at room temperature under daylight and UV light $(\lambda=365 \mathrm{~nm})$.

\section{RESULTS AND DISCUSSION}

\section{Spectroscopic Studies FT-IR studies}

The IR spectrum of the Schiff base is given in Figure 1. The vibration bands with the wavenumbers $\left(v, \mathrm{~cm}^{-1}\right)$ of $3291(\mathrm{Ar}-\mathrm{OH}), 3077$ $($ Ar-H), 2925 (aliph-H), $1598(\mathrm{C}=\mathrm{N}+\mathrm{C}=\mathrm{C}), 1558$ $(\mathrm{C}=\mathrm{C}), 1497(\mathrm{C}-\mathrm{N}), 1346(\mathrm{C}-\mathrm{O})$ and 1262-1220$1169-1050 \mathrm{~cm}^{-1}\left(\mathrm{Ar}-\mathrm{O}-\mathrm{CH}_{3}\right)$ were observed in the spectrum. Also, the $\mathrm{C}=\mathrm{N}$ and $\mathrm{C}=\mathrm{C}$ peaks overlap at $1598 \mathrm{~cm}^{-1}$ in the spectrum (Figure 1 ). Due to the intramolecular hydrogen bond $\mathrm{O}-\mathrm{H} \ldots \mathrm{N}$, a peak at $2828 \mathrm{~cm}^{-1}$ was observed in the spectrum of the compound. The presence of a strong band at $1346 \mathrm{~cm}^{-1}$ in the Schiff base indicates that the compound is in phenol-imine form due to the stabilization of the phenolic $\mathrm{C}-\mathrm{O}$ bond. Very strong etheric ArC-O-C vibrations were observed between $1262 \mathrm{~cm}^{-1}$ and $1050 \mathrm{~cm}^{-1}$ for the compound.

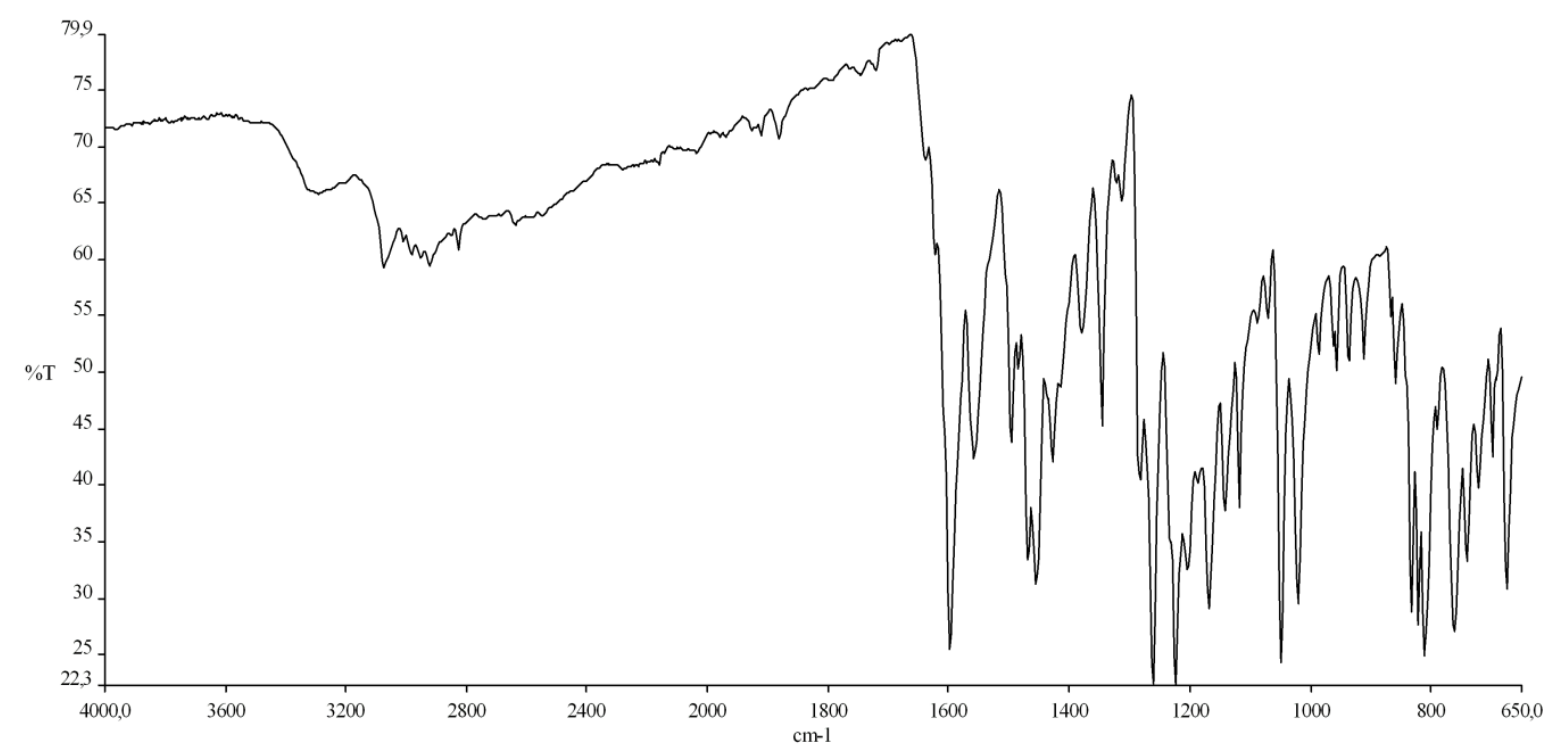

Figure 1. FTIR spectrum of the Schiff base.

\section{${ }^{1} H$ - and ${ }^{13}$-CNMR spectroscopy}

The NMR spectrum of the compound is given in Figures 2 and 3 . According to the ${ }^{1} \mathrm{H}$ NMR results, the Schiff base has phenol-imine form in DMSO solution (Fig. 2). In the NMR spectrum of the compound, a singlet for the $\mathrm{OC}_{3}$ protons, and multiplets for the $\mathrm{Ar}-\mathrm{H}$ protons are observed. In the compound, the $\mathrm{O} \underline{\mathrm{H}}$ and $-\mathrm{CH}=\mathrm{N}$ - protons are observed as a singlet. It can be said that the compound is in phenol-imine form in DMSO since the imine $(-\underline{\mathrm{C}}=\mathrm{N}-)$ and hydroxyl $(\mathrm{O} \underline{\mathrm{H}})$ protons do not split. From the ${ }^{13} \mathrm{C}$ NMR spectrum, it appears that the compound has 15 signals (Figure 3 ). When the chemical shift values are ordered from highest to lowest, they are $\mathrm{N}-\underline{\mathrm{C}}(\mathrm{S})-,-\underline{\mathrm{C}} \mathrm{H}=\mathrm{N}, \mathrm{Ar} \underline{\mathrm{C}}-$ $\mathrm{OH}, \mathrm{Ar} \underline{\mathrm{C}}-\mathrm{OCH}_{3}, \mathrm{Ar}-\underline{\mathrm{C}}$, and $\mathrm{O} \underline{\mathrm{C}} \mathrm{H}_{3}$, respectively, for the compound. According to the NMR results, the compound is in the phenol-imine form in DMSO solution. 


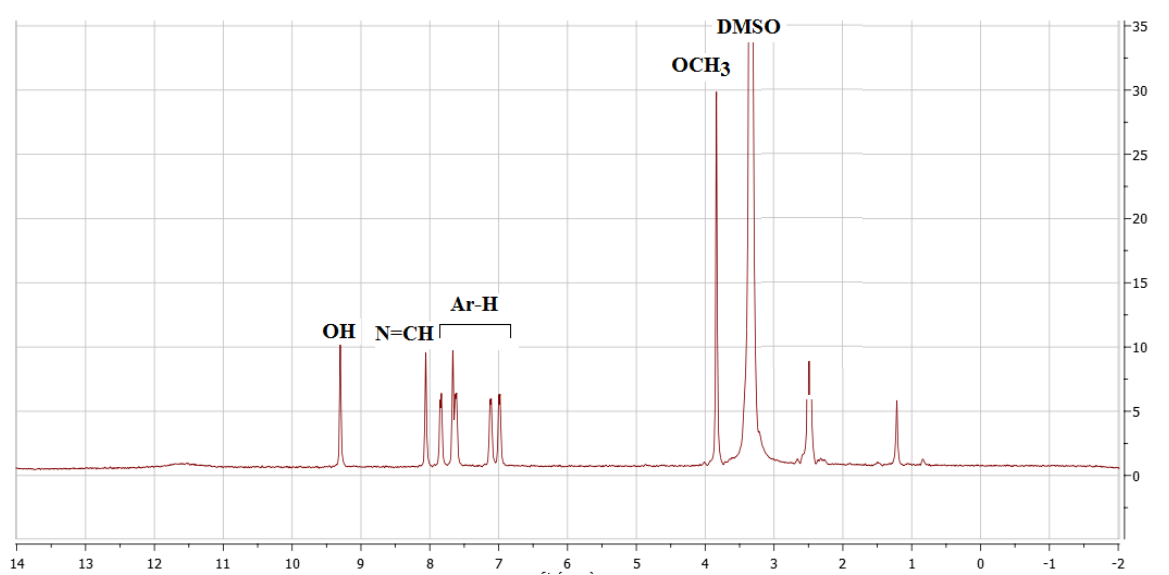

Figure 2. ${ }^{1} \mathrm{H}-\mathrm{NMR}$ spectra of the Schiff base.

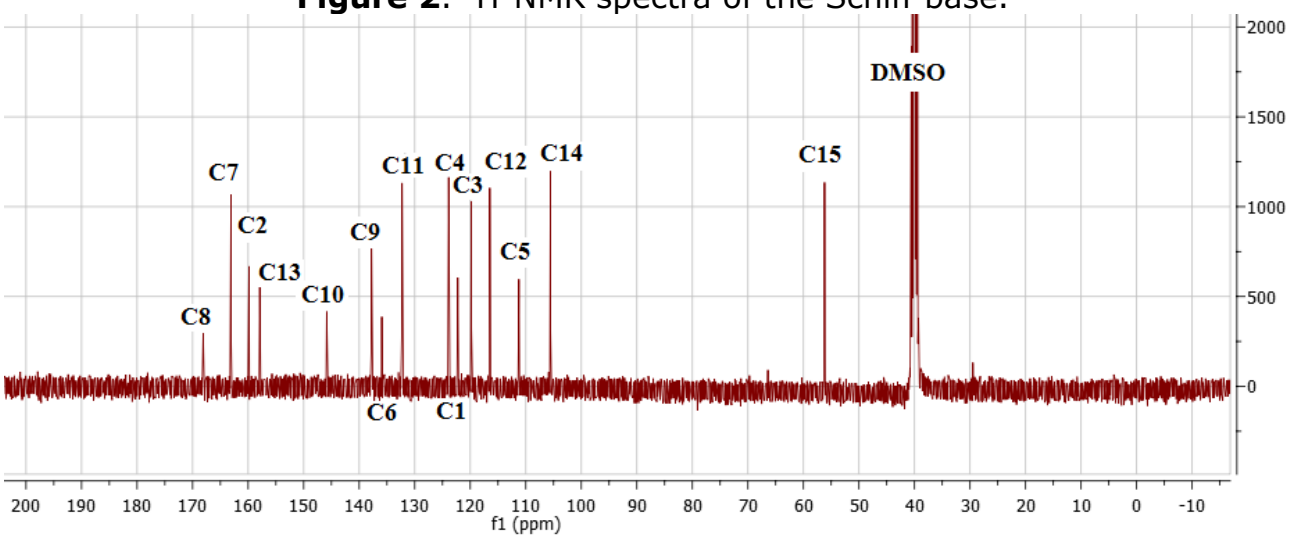

Figure 3. ${ }^{13} \mathrm{C}-\mathrm{NMR}$ spectra of the Schiff base.

\section{UV-Vis spectroscopy}

In this study, the electronic spectrum of the compound was also investigated in dimethyl sulfoxide (Figure 4). Some imines give absorption bands in both polar and non-polar solvents greater than $400 \mathrm{~nm}$. It was reported that the new band in 2-hydroxy imines belongs to the keto-amine form in polar and non-polar solvents in both acidic and basic solutions. A new peak was not observed after $400 \mathrm{~nm}$ in DMSO for the Schiff

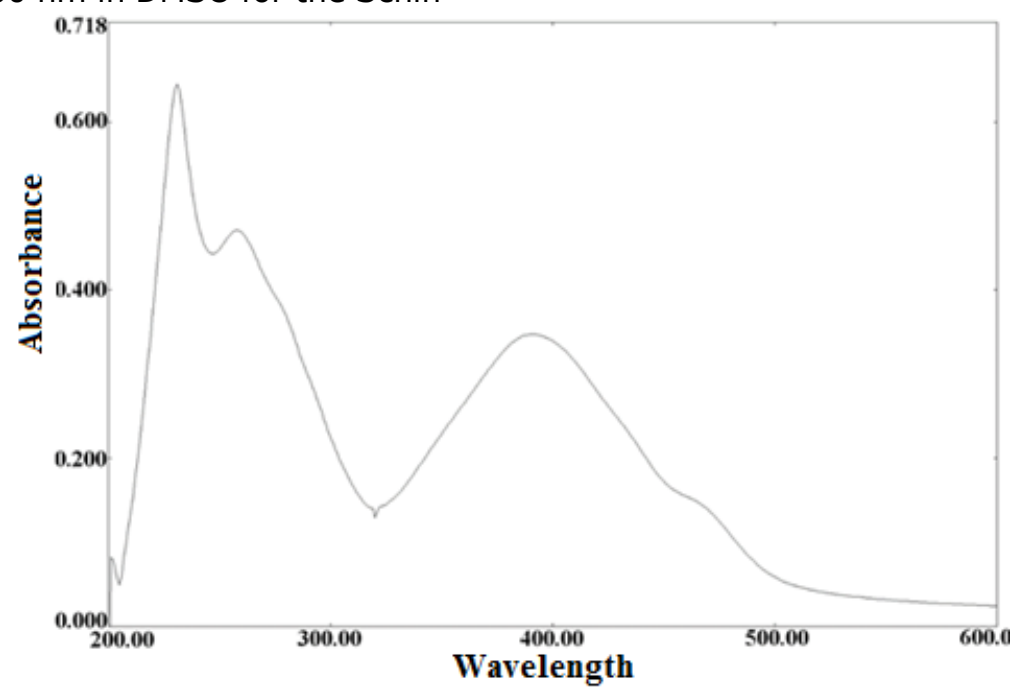

Figure 4. UV-Vis spectrum of the Schiff base.

Colorimetric anion sensing of the compound For the colorimetric anion sensor properties of the Schiff base, the color of the solution formed by the addition of anions to the DMSO solution base. Hence, the compound has phenol-imine form in DMSO. According to the UV-Vis results of the compound, only a shoulder and a band appear at $276 \mathrm{~nm}$ and $399 \mathrm{~nm}$, which are assigned to the $n-\Pi^{*}$ and $n-\Pi^{*}$ transition of the $\mathrm{C}=\mathrm{C}$ and $\mathrm{C}=\mathrm{N}$.

As a result, the compound was in the phenolimine form according to the FTIR, UV-Vis, ${ }^{13} \mathrm{C}$ NMR and ${ }^{1} \mathrm{H}-\mathrm{NMR}$ data. 
As shown in the photographs taken under two different lights, the color of the compound changes with the addition of $\mathrm{F}^{-}, \mathrm{CN}^{-}, \mathrm{AcO}^{-}, \mathrm{H}_{2} \mathrm{PO}_{4}^{-}$ and $\mathrm{OH}^{-}$anions to the sensor compound (Figures 5a; under day light, 5b and 5c; under UV lamp). In daylight, the observed color changes were from yellow to red for $\mathrm{F}^{-}$and $\mathrm{CN}^{-}$, dark orange for AcO- and $\mathrm{OH}^{-}$, and to light orange for $\mathrm{H}_{2} \mathrm{PO}_{4}^{-}$(Fig. 5a). Significant fluorescence changes were observed under long-wave UV lamp for anions (Figure $5 b$ ). The color of the anion solutions is light-red for $\mathrm{F}^{-}$and $\mathrm{CN}^{-}$, and it is light-orange for $\mathrm{AcO}^{-}, \mathrm{H}_{2} \mathrm{PO}_{4}^{-}$and $\mathrm{OH}^{-}$. There were more pronounced fluorescence changes under the shortwave UV lamp. In the solutions, turquoise and light-red were observed for $\mathrm{F}^{-}, \mathrm{AcO}^{-}, \mathrm{H}_{2} \mathrm{PO}_{4}^{-}$ and $\mathrm{OH}^{-}$, and $\mathrm{CN}^{-}$, respectively. Intensive color change is formed by the addition of anions such as $\mathrm{F}^{-}, \mathrm{CN}^{-}, \mathrm{AcO}^{-}, \mathrm{H}_{2} \mathrm{PO}_{4}^{-}$and $\mathrm{OH}^{-}$. This shows that there is strong binding between these selective ions and the Schiff base. For the above anions, the sensor compound gave a visible color change under both the short wave and the long wave UV lamp. There is no visible color or fluorescence change for all other less basic anions ( $\mathrm{Br}^{-}, \mathrm{I}^{-}, \mathrm{SCN}^{-}$ , $\mathrm{ClO}_{4}^{-}$and $\mathrm{HSO}_{4}^{-}$) studied under both daylight and UV lamp. Accordingly, we can say that there is very weak binding or no binding between these anions and the Schiff base.
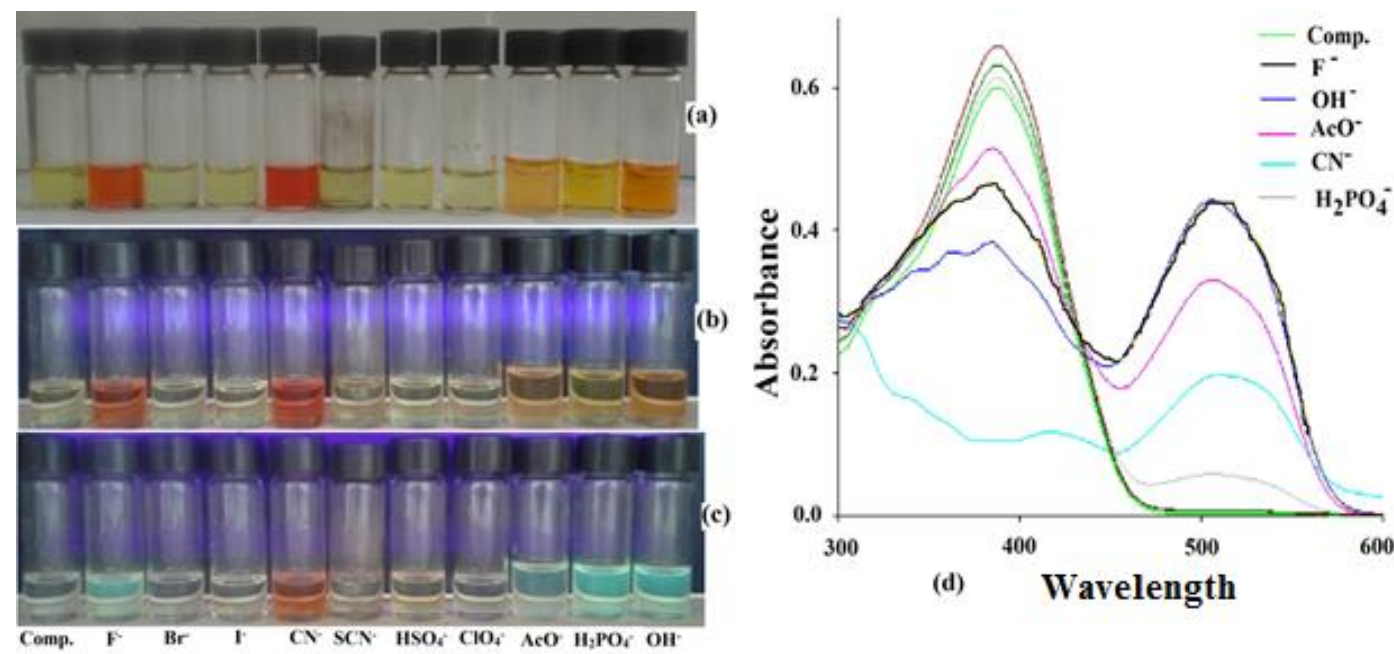

Figure 5. a) Color changes of compound (50 $\mu \mathrm{M})$ under normal light, b) hand held UV lamp $(\lambda=365 \mathrm{~nm})$, c) hand held UV lamp $(\lambda=254 \mathrm{~nm})$, d) UV-Vis absorption spectra upon the addition of 1.0 equivalence of various anions in DMSO.

The ability of Schiff base $(50 \mu \mathrm{M})$ to detect $\mathrm{F}^{-}, \mathrm{CN}^{-}$ , $\mathrm{AcO}^{-}, \mathrm{H}_{2} \mathrm{PO}_{4}^{-}$and $\mathrm{OH}^{-}$anions was studied using UV-Visible spectrophotometry in DMSO as shown in Figure 5c. A band at $385 \mathrm{~nm}$ in the UV-Vis spectrum for the Schiff base was observed before the addition of the selective anions. When the $\mathrm{F}^{-}$, $\mathrm{CN}^{-}, \mathrm{AcO}^{-}, \mathrm{H}_{2} \mathrm{PO}_{4}^{-}$and $\mathrm{OH}^{-}$anions were gradually added, the intensity of the band decreased at 385 $\mathrm{nm}$ and a new band was formed at $505 \mathrm{~nm}$. In 2hydroxy Schiff bases, the absorption band at $>$ $400 \mathrm{~nm}$ was reported to belong to the ketamine form (32). In this case, the keto-amine form occurs because the $\mathrm{H}$ atom from the $\mathrm{O}-\mathrm{H}$ group is transferred to the $\mathrm{N}$ atom of the $\mathrm{CH}=\mathrm{N}$ group. This resulted in a change of color from yellow to red and orange. This band was probably due to the intramolecular charge transfer of electrons, which are resultant phenol protons and the anion interactions (16-20). All the other anions $\left(\mathrm{Br}^{-}\right.$, $\mathrm{HSO}_{4}^{-}, \mathrm{Cl}^{-}$and $\mathrm{ClO}_{4}^{-}$) did not exhibit any discernible changes (15-20). UV-Vis results show that the Schiff base exhibits excellent selectivity for $\mathrm{F}^{-}, \mathrm{CN}^{-}, \mathrm{AcO}^{-}, \mathrm{H}_{2} \mathrm{PO}_{4}^{-}$and $\mathrm{OH}^{-}$anions in the presence of other anions and can be useful in practical applications. Furthermore, the anionbinding capacity of the compound was found to be $\mathrm{F}^{-}>\mathrm{OH}^{-}>\mathrm{AcO}^{-}>\mathrm{CN}^{-}>\mathrm{H}_{2} \mathrm{PO}_{4}^{-}$using a UV-Visible spectrophotometer, respectively.
In our previous study, while the salicylaldehydebased sensor did not show selectivity against phosphate anion (17), the 5bromosalicylaldehyde-based sensor showed selectivity against phosphate in this study. In this study, addition of phosphate anion to the DMSO solution of the 5-bromosalicylaldehyde-based sensor resulted in a rapid color change from yellow to light orange with an accompanying new band appearing at $505 \mathrm{~nm}$ in the absorption profile. The title compound showed chromogenic and fluorogenic sensor properties against phosphate anion. In addition, for the same anions under both daylight and UV lamp, each sensor gave a different solution color. Consequently, it can be said that the substituted bromine in the title compound affects the anion selectivity.

These results demonstrate that the receptor title Schiff base exhibits good selectivity for $\mathrm{F}^{-}, \mathrm{OH}^{-}$, $\mathrm{AcO}^{-}, \mathrm{CN}^{-}$and $\mathrm{H}_{2} \mathrm{PO}_{4}^{-}$anions in the presence of other anions and is useful in practical applications.

\section{Minimum Inhibitory Concentration (MIC)}

Minimum inhibition concentration (MIC) was determined with broth microdilution test. The average of three experimental results is given in Table 1 . The antimicrobial activity spectrum of the 
Schiff base showed great diversity. As can be seen from Table 1, it can be said that Schiff base antimicrobial activity results have a similar effect against bacteria and yeast. This compound showed activity against the tested microorganisms. Surprisingly, the compound exhibits similar activity, although Gram-positive, Gram-negative and yeast cell walls are very different.

Table 1. MIC $(\mu \mathrm{g} / \mathrm{mL})$ of the compound.

\begin{tabular}{|c|c|c|c|}
\hline \multirow[t]{2}{*}{ Microorganisms } & \multirow[t]{2}{*}{ Compound } & \multicolumn{2}{|c|}{ Antibiotic } \\
\hline & & Ampicillin & Fluconazole \\
\hline S. aureus ATCC 25923 & 256 & 5 & - \\
\hline E. faecalis ATCC 29212 & 128 & 8 & - \\
\hline E. coli ATCC 25922 & 128 & - & - \\
\hline P. aeruginosa ATCC 254992 & 256 & 5 & - \\
\hline C. albicans ATCC 60193 & 128 & - & 128 \\
\hline C. tropicalis ATCC 13803 & 128 & - & 64 \\
\hline
\end{tabular}

\section{Interaction of Schiff base and DNA}

The effect of Schiff base on CT-DNA was investigated using electronic spectroscopy. With the increase in the concentration of CT-DNA, decreases of $18.89-56.26 \%$ and $13.50-20.00 \%$, and higher wavelength of 1-37 nm and 1-3 nm are observed at $258 \mathrm{~nm}$ and $390 \mathrm{~nm}$ (Figure 6). Furthermore, the red shift of maximum absorption shows the energy decrease in energy between the HOMO and LUMO. This indicates that

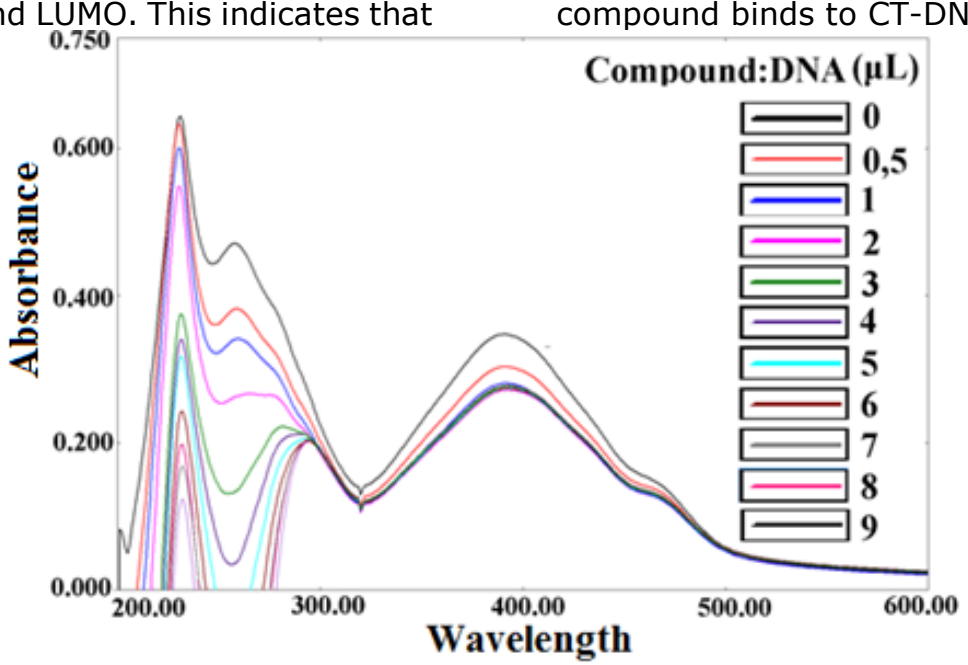

DNA interacts with the Schiff base (14-20). If the DNA interacts with the Schiff base, $\Pi-\Pi^{*}$ transition energy decreases, and the absorption shifts to red. The decrease, increase and shift long wave of absorption in the UV absorption spectra show that the Schiff base interacts with CT-DNA, presumably because of stacking of the interaction between an aromatic ring and the base pairs of DNA (14-20). According to the UV-Vis results, the compound binds to CT-DNA intercalatively. at room temperature in Tris- $\mathrm{HCl} / \mathrm{NaCl}$ buffer $(\mathrm{pH} 7.2)$.

\section{DNA-Cleavage activity}

The cleavage of DNA is determined with the agarose gel electrophoresis method. Supercoiled (SC) plasmid pBR322 DNA was used in the study. Cleavage experiments were performed by adding Schiff base at concentrations ranging from $5 \mu \mathrm{M}$ to $400 \mu \mathrm{M}$ in TAE buffer.
If the DNA interacts with the Schiff base, SC DNA form is degraded to nicked circular (NC) form. According to the result of the cleavage assay, it is seen that the SC form of DNA is preserved (Fig.7). Consequently, the Schiff base which is both hydrolytic and oxidative does not show any cleavage of SC DNA (Figure 7 a: hydrolytic b: oxidative). 


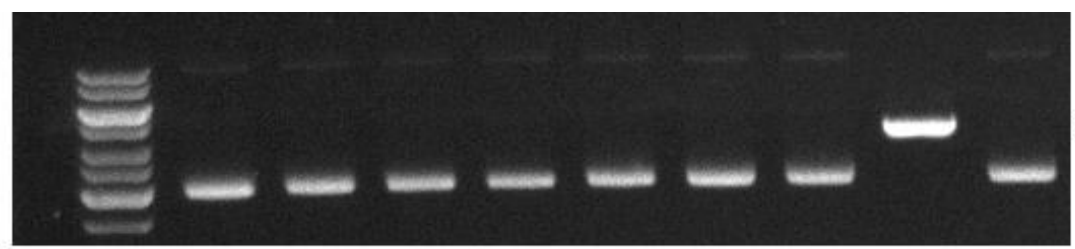

Marker DNA $5 \mu \mathrm{L} \quad 25 \mu \mathrm{L} \quad 50 \mu \mathrm{L} \quad 100 \mu \mathrm{L} 200 \mu \mathrm{L} 400 \mu \mathrm{L} \quad$ EB $\quad$ DMSO

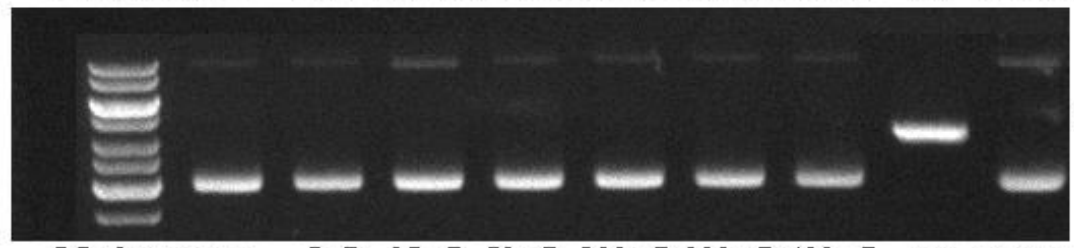

(b)

Marker DNA $5 \mu \mathrm{L} \quad 25 \mu \mathrm{L} \quad 50 \mu \mathrm{L} \quad 100 \mu \mathrm{L} 200 \mu \mathrm{L} 400 \mu \mathrm{L} \quad$ EB DMSO

Figure 7. Agarose gel electrophoresis patterns for the hydrolytic cleavage of pBR322 DNA by Schiff base. DNA: Deoxyribonucleic acid; $\mu$ L: Microliters; EB: Ethidium bromide; DMSO: Dimethyl sulfoxide.

\section{CONCLUSIONS}

In this work, a benzothiazole-based Schiff base was synthesized and its structure was elucidated. In addition, biological activity and chemical sensor applications were investigated. Minimum inhibitory concentration (MIC) against yeast and bacteria was determined. Interactions with DNA were studied. It was found that it binds interactively to DNA, but it does not cleave DNA. The sensor properties were tested against anions. The Schiff base was found to be selective for fluoride, cyanide, acetate, dihydrogen phosphate and hydroxyl anions in DMSO. A color change was observed for these anions, but not for the other anions. As a result of all these studies, it was found that it could be used as an agent for DNA and anions.

\section{REFERENCES}

1. Kajal A, Bala S, Kamboj S, Saini V. Schiff Bases: A versatile pharmacophore. J. Catal. 2013 August; 1-14.

2. Kumar S. Protease inhibiting and other biological activities of Schiff base derivatives. IJRT. 2016; 2(7):439-54.

3. Luo $H$, Xia $Y-F$, Sun $B-F$, Huang $L-R$, Wang $X-H$, Lou $\mathrm{H}-\mathrm{Y}$, Zhu $\mathrm{X}-\mathrm{H}$, Pan W-D, Zhang $\mathrm{X}-\mathrm{D}$. Synthesis and evaluation of in vitro antibacterial and antitumor activities of novel $\mathrm{N}, \mathrm{N}-$ disubstituted Schiff bases. Biochem. Res. Int. 2017 Jun; 2017:6257240.

4. Guo Z, Xing R, Liu S, Zhong $Z$, Ji X, Wang L, Li P. Antifungal properties of Schiff bases of chitosan, N-substituted chitosan and quaternized chitosan. Carbohydr. Res. 2007; 342(10):132932.

5. Przybylski P, Huczynski A, Pyta K, Brzezinski B, Bartl F. Biological properties of Schiff bases and azo derivatives of phenols. Curr. Org. Chem. 2009; 13(2):124-48.
6. Li H-G, Yang Z-Y, Qin D.D. A new Schiff-base type selective fluorescent chemosensor for $\mathrm{Cu} 2+$. Inorg. Chem. Commun. 2009 June; 12 (6):4947.

7. Zhu W, Yang L, Fang M, Wu Z, Zhang Q, Yin F, Huang Q, Li C. New carbazole-based Schiff base: Colorimetric chemosensor for $\mathrm{Fe} 3+$ and fluorescent turn-on chemosensor for $\mathrm{Fe} 3+$ and Cr3+. J. Lumin. 2015 February; 158:38-43.

8. Gupta V.K, Singh A.K, Kumawat L.K. Thiazole Schiff base turn-on fluorescent chemosensor for $\mathrm{Al} 3+$ ion. Sens. Actuat. B: Chem. 2014 May; 195:98-100.

9. Singh T.S, Paul P.C, Pramanik H.A. Fluorescent chemosensor based on sensitive Schiff base for selective detection of $\mathrm{Zn} 2+$. Spectrochim. Acta A Mol. Biomol. Spectrosc. 2014; 121:520-6.

10. $\mathrm{Xu} \mathrm{Y,} \mathrm{Aderinto} \mathrm{S.O,} \mathrm{Wu} \mathrm{H,} \mathrm{Peng} \mathrm{H,} \mathrm{Zhang} \mathrm{H}$, Zhang J, Fan $X$. A highly selective fluorescent chemosensor based on naphthalimide and Schiff base units for $\mathrm{Cu} 2+$ detection in aqueous medium. Z. Naturforsch. B. 2016; 72(1):35-41.

11. Hijji Y.M, Barare B, Kennedy A.P, Butcher R. Synthesis and photophysical characterization of a Schiff base as anion sensor. Sens. Actuators B: Chem. 2009 March; 136(2): 297-302.

12. Dalapati S, Jana S, Guchhait N. Anion recognition by simple chromogenic and chromofluorogenic salicylidene Schiff base or reducedSchiff base receptors. Spectrochim. Acta A Mol. Biomol. Spectrosc. 2014 Aug; 129:499-508.

13. Mohammadi A, Jabbari J. Simple naked-eye colorimetric chemosensors based on Schiff-base for selective sensing of cyanide and fluoride ions. Can. J. Chem. 2016; 94(7): 631-6.

14. Yıldız $M$, Demir $N$, Ünver $H$, Sahiner $N$. Synthesis, characterization, and application of a novel water-soluble polyethyleneimine-based Schiff base colorimetric chemosensor formetal 
cations and biological activity. Sens. Actuators B: Chem. 2017 May; 252: 55-61.

15. Zeyrek C.T, Boyacioğlu B, Yıldız M, Ünver $H$, Yolal D, Demir N, Elmali A, Tadesse S, Aslan K. Synthesis, characterization, and evaluation of (E)-methyl-2-((2-oxonaphthalen-1(2H)-

ylidene)methylamino)acetate as a biological agent and an anion sensor. Bioorg. Med. Chem. 2016 Sept.; 24:5592-601.

16. Ünver $H$, Boyacıoglu B, Zeyrek C.T, Yıldız M, Demir N, Yıldırım N, Karaosmanoğlu O.K, Sivas H, Elmalı A. Synthesis, spectral and quantum chemical studies and use of (E)-3-[(3,5bis(trifluoromethyl)phenylimino)methyl]benzene-1,2-diol and its $\mathrm{Ni}(\mathrm{II})$ and $\mathrm{Cu}$ (II) complexes as an anion sensor, DNA binding, DNA cleavage, anti-microbial, antimutagenic and anti-cancer agent. J. Mol. Struct. 2016 June; 1125:162-76.

17. Barare $B$, Yıldız $M$, Ünver $H$, Aslan $K$. Characterization and use of (E)-2-[(6methoxybenzo[d]thiazol-2-

ylimino)methyl]phenol as an anion sensor and a DNA-binding agent. Tetrahedron Lett. 2016; 57:537-42.

18. Yıldız M, Tan E, Demir N, Yıldırım N, Ünver $H$, Kiraz A, Mestav B. Synthesis and spectral, antimicrobial, anion sensing, and DNA binding properties of Schiff base podands and their metal Complexes1. Russ. J. Gen. Chem. 2015; 85(9):2149-62.

19. Barare B, Yıldız M, Alpaslan G, Dilek N, Ünver $\mathrm{H}$, Tadesse $\mathrm{S}$, Aslan K. Synthesis, characterization, theoretical calculations, DNA binding and colorimetric anion sensing applications of $1-[(E)-[(6-m e t h o x y-1,3-$ benzothiazol-2-yl)imino]methyl]naphthalen-2-ol. Sens. Actuat. B: Chem., 2015 March; 215:52-61.

20. Yıldız M, Karpuz Ö, Zeyrek C.T, Boyacioğlu B, Dal H, Demir N, Yıldırım N, Ünver H. Synthesis, biological activity, DNA binding and anion sensors, molecular structure and quantum chemical studies of a novel bidentate Schiff base derived from 3,5-bis(triflouromethyl)aniline and salicylaldehyde. J. Mol. Struct. 2015 April; 1094:148-60.

21. Yeap G.-Y, Ha S.-T, Ishizawa N, Suda K, Boey P.-L, Mahmood W.A.K, Synthesis, crystal structure and spectroscopic study of parasubstituted

2-hydroxy-3methoxybenzalideneanilines. J. Mol. Struct. 2003; 658:87-99.

22. Martínez-Máñez R, Sancenón F. Fluorogenic and chromogenic chemosensors and reagents for anions. Chem. Rev. 2003; 103:4419-76.

23. Uysal UD, Berber $H$, Ercengiz D. Theoretical investigation on solvent dependent shift and electronic transition properties of certain Schiff bases. JOTCSA, 2018; (4-sp.is.1): 111-30.

24. Kang J, Song E.J, Kim H, Kim Y-H, Kim Y, Kim S-J, Kim C. Specific naked eye sensing of cyanide by chromogenic host: studies on the effect of solvents. Tetrahedron lett. 2013 february; 54:1015-19.

25. Piątek $P$, Jurczak J, A selective colorimetric anion sensor based on an amide group containing macrocycle. Chem. Commun. 2002; 20:2450-1.

26. Gan C, Zhou L, Zhao Z, Wang H. Benzothiazole Schiff-bases as potential imaging agents for $\beta$-amyloid plaques in Alzheimer's disease. Med. Chem. Res. 2013; 22(9): 4069-74.

27. Piscitelli F, Ballatore C, Smith A. Solid phase synthesis of 2-aminobenzothiazoles. Bioorg. Med. Chem. Lett. 2010; 20(2):644-8.

28. Ali R, Siddiqui N. Biological Aspects of Emerging Benzothiazoles: A Short Review. J. Chem. 2013; 1-12.

29. Vijayalakshmi $R$, Kanthimathi $M$, Parthasarathi R, Nair B.U, Interaction of chromium(III) complex of chiral binaphthyl tetradentate ligand with DNA. Bioorg. Med. Chem. 2006 May; 14:3300-6.

30. Li F, Feterl M, Mulyana Y,. Warner J.M, Collins J.G, Keene F.R. In vitro susceptibility and cellular uptake for a new class of antimicrobial agents: Dinuclear ruthenium(II) complexes. J. Antimicrob. Chemother. 2012; 67:2686-95.

31. Marmur J. A procedure for the isolation of deoxyribonucleic acid from micro-organisms. J. Mol. Biol. 1961 April; 3:208-18.

32. Nazır H, Yıldız M, Yılmaz H, Tahir M.N, Ülkü D. Intramolecular hydrogen bonding and tautomerism in Schiff bases. Structure of $\mathrm{N}-(2-$ pyridil)-2-oxo-1-naphthylidenemethylamine. J. Mol. Struct. 2000 June; 524:241-50. 